\title{
The Impact of Financial Inclusion on Residents' Investments in the Digital Economy
}

\author{
Niu Ziyao ${ }^{1}$, Huang Nuoxin ${ }^{2 *}$ \\ ${ }^{1}$ Department of Majoring in Economics, Northeastern University, Shenyang, Liaoning, China \\ ${ }^{2}$ Department of Research Institute of Economics and Management, Southestern University of Finance and Economics, \\ Chengdu, China \\ *huangnuoxin0828@163.com
}

\begin{abstract}
In order to address the problems of low returns on residents' savings, few investment channels and uneven distribution of financial resources, this paper constructs a Probit model to discuss the impact of digital financial inclusion on residents' investment decisions; and a Tobit model to discuss the impact of the digital economy financial inclusion index on the amount of investment generated. The experiment results show that digital financial inclusion has a positive impact on residents' investment and investment amount, and can promote residents' investment and increase their investment amount. Influenced by regional characteristics and individual traits, the promotion effect of digital finance on investment is more significant in the eastern region and the group with high education levels. In view of this, this paper puts forward proposals to expand the coverage of financial services and improve the imbalance in the allocation of financial resources; introduce various financial products to enhance the quality of financial services; and popularize financial knowledge to benefit the disadvantaged groups at the grassroots level.
\end{abstract}

\section{Keywords: Digital Inclusive Finance Resident investment Regional differences Differences in the} level of education

\section{INTRODUCTION}

In its Global Investment Report 2017, UNCTAD (United Nations Conference on Trade and Development) defines the digital economy and explains that it is becoming an increasingly important part of the global economy. Among the main points of the report are: 1 . Digital development in all countries, particularly developing countries' inclusion in the global digital economy, requires targeted investment policy support to build infrastructure connectivity facilities, encourage digital companies, and support the digitisation of the entire economy.2. Digital development should be embedded in investment policies, and investment policies should be embedded in digital development strategies.3. In supporting investment in digital development At the same time, policymakers also need to address public concerns about digital development. It can be seen that the digital economy has become a key driving force for China's economic and social development. Economic and social development depends not only on residents' consumption but also on residents' investment, which in turn plays a very significant role in the healthy development of China's economy and the flow of social capital.

With the advent of the new era of the digital economy and the prevalence of inclusive finance in the digital economy, residential investment has also undergone significant changes. Household financial decisions are an important part of microfinance, and residential investment is the key to household financial decisions. Previous studies by scholars on resident investment have mainly focused on the internal influencing factors in terms of individual household asset allocation, and many other kinds of literature have studied the impact of Internet finance on traditional financial industries and resident financial investment, and the regulation of Internet finance, while relatively little research has been conducted on the impact of inclusive finance on resident investment in the digital economy. This article explores the impact on residents' investment from this relatively new perspective, in order to complement current research and provide indicative advice for future investment market development. Household financial decisions include major consumption and savings, investment and 
financing. In recent years, Chinese residents' securities assets have risen compared to cash and savings deposits, but the latter still dominates, while the returns on savings are low and residents face difficulties in preserving value and few investment channels, etc. The digital economy promotes financial services for all, greatly changing residents' productive life, consumption payments and investment and financial services. The digital economy has boosted the popularization of financial services, which has largely changed residents' production and life, consumption and payment, and investment and finance. By studying the impact of inclusive finance on residents' investment in the digital economy era, this paper analyses the current situation and problems of residents' investment, and gives some suggestions to current financial service institutions, namely Internet financial services and traditional financial services, to help them recognise the market demand and create diversified and differentiated products suitable for diversified and differentiated investment products for different service groups.

Therefore, this paper uses data from the China Household Tracking Survey (CFPS) released by the China Social Science Survey Centre (ISSS) of Peking University to explore the impact on residents' investment and establishes a binary Probit model to explore the impact of digital finance on residents' investment decisions. Since there will be residents who have not invested and the amount of investment is zero, the amount of investment is not exactly a continuous variable, and there are truncated variables. A Tobit model is established to discuss the impact of digital finance on the amount of investment made by residents. With the degree of financial inclusion in the digital economy as the core, a comparative analysis of the differences in the impact of investment in different regions by residents with varying levels of education, while also taking into account individual and household characteristics; finally, a brief prediction of changes in resident investment and corresponding recommendations for financial service providers.

\section{LITERATURE REVIEW}

Resident investment refers to the purchase of incomegenerating assets by residents, including the purchase of physical assets engaged in production and business activities and the purchase of financial assets such as stocks and bonds. Resident investment can effectively alleviate the shortage of domestic construction funds and help to promote the adjustment of China's industrial structure and the effective allocation of capital. At the same time, the study of resident investment in the digital economy can provide constructive advice for reforming China's future investment system. The development of a country cannot only look at macrofinance, but also needs to focus on analyzing microfinance, and household financial decisions are an important part of microfinance, of which resident investment is again the key to household financial decisions.

The asset portfolio theory proposed by Markowitz (1952) provided a theoretical basis for later scholars to study resident investment and household financial assets, and also provided some factors that had an impact on resident investment, some of which were studied from the perspective of physical capital, such as household income, assets and borrowing constraints on the impact that resident investment choices in financial asset portfolios could have. Later, scholars' studies began to explore the human capital differences from the perspective that investment activities in financial markets such as stocks require a certain level of financial knowledge, as well as the ability to acquire and process financial information, which mainly includes education level (Xiao Zuoping and Zhang Xinzhe, 2012), financial knowledge (Yin Zhichao et al., 2014), cognitive ability (Meng Yijia, 2014), and health level (Lei Xiaoyan and Zhou Yuegang, 2010). In addition to this, there are also literature exploring factors that influence household financial investment participation at the level of social interaction and social capital (Li Tao and Liu Yucan 2006; Meng JuanJuan et al. 2013), marriage and other sociodemographic factors (WangJin and $\mathrm{Wu}$ Weixing 2014), and macroeconomic policies (Lin Bo 2018). With the development of the Internet, the literature has also begun to examine the impact of Internet finance and market frictions on the traditional financial sector and residents' financial investment (Zhou Guangsu and Liang Qi, 2018). In contrast, relatively little research has been conducted on the impact of financial inclusion on residents' investment in the digital economy. The available literature has mainly focused on the effect of the Internet on residents' investment, and the degree of Internet penetration and digital financial development are inherently different across regions.

\section{STUDY DESIGN}

\subsection{Data sources}

This paper uses data from the 2018 China Household Tracking Survey (CFPS) and data reported by the Digital Finance Research Centre of Peking University. The former data is published by the China Social Science Survey Centre (ISSS) of Peking University and covers all members of 16,000 households in 25 provinces, municipalities and autonomous regions of China. The latter data is published by Peking University's Digital Finance Research Centre, covering 31 provinces (municipalities directly under the Central Government and autonomous regions), 337 cities (regions, autonomous regions, leagues, etc.) at the prefectural level and above, and about 2,800 counties (county-level cities, banners, municipal districts, etc.) in China from 2010 to 
2020. According to the Peking University Digital Financial Inclusion Index, this paper focuses on the Digital Inclusive Finance Index of Peking University from 2010 to 2020. This paper focuses on the impact of inclusive finance on residents' investment in the digital economy. The extent of digital financial development and the amount of investment by residents are obtained from the Peking University Digital Inclusive Finance Index report, the CFPS database and the adult questionnaire. In order to make the sample more representative, this paper adopts the way of eliminating missing values and taking logarithms of some variables to process the data, and finally retains a valid sample of 11,798 .

\subsection{Selection of variables}

\section{Explanatory variables}

Firstly, residents' investment decisions were identified as the explanatory variable, based on the question of "Does your household currently hold financial products, such as stocks, funds, government bonds, trust products, foreign exchange products, etc.?" in the CFPS2018 questionnaireto determine residents' investment decisions. Secondly, non-zero resident investment is defined as a continuous variable. Based on the question in the CFPS2018 questionnaire, "What is the total value of all financial products currently held by your household?" to select the amount invested by residents.

\section{Core explanatory variables}

The degree of digital financial development is used as a core explanatory variable. The 2018 Digital Inclusive Finance Index was selected as the core explanatory variable based on data screened from the report "Digital Inclusive Finance Index of Peking University" published by the Digital Finance Research Centre of Peking University.

\section{Control variables}

Based on the research of some scholars, this paper introduces the factors of individual characteristics and the social environment of the residents. The individual characteristics include gender, age, marriage, health status, education level and income.

Table 1 Description of variables

\begin{tabular}{|c|l|}
\hline Variable name & \multicolumn{1}{|c|}{ Variable Description } \\
\hline $\begin{array}{c}\text { Investment } \\
\text { decisions }\end{array}$ & No =0, Yes = 1 \\
\hline $\begin{array}{c}\text { Resident } \\
\text { investment }\end{array}$ & $\begin{array}{c}\text { Continuous variables other than } \\
\text { truncated variables with Inv_des=0 }\end{array}$ \\
\hline $\begin{array}{c}\text { Digital } \\
\text { Inclusion } \\
\text { Index }\end{array}$ & $\begin{array}{l}\text { From the Peking University Digital } \\
\text { Inclusion Index Report }\end{array}$ \\
\hline $\begin{array}{c}\text { Breadth of } \\
\text { coverage }\end{array}$ & $\begin{array}{l}\text { From the Peking University Digital } \\
\text { Inclusion Index Report }\end{array}$ \\
\hline Depth of use & $\begin{array}{l}\text { From the Peking University Digital } \\
\text { Inclusion Index Report }\end{array}$ \\
\hline
\end{tabular}

\begin{tabular}{|c|l|}
\hline $\begin{array}{c}\text { Degree of } \\
\text { digitalization }\end{array}$ & $\begin{array}{l}\text { From the Peking University Digital } \\
\text { Inclusion Index Report }\end{array}$ \\
\hline $\begin{array}{c}\text { Resident } \\
\text { income }\end{array}$ & Total income for the past 12 months (\$) \\
\hline Age & Age, continuous variable \\
\hline Gender & Female=0, Male=1 \\
Health status & $\begin{array}{l}\text { Health self-assessment: unhealthy=1, } \\
\text { fair=2, relatively healthy=3, very } \\
\text { healthy=4, very healthy=5 }\end{array}$ \\
\hline Work status & $\begin{array}{l}\text { No=0, Yes=1, withdrawn from labour } \\
\text { market=3 }\end{array}$ \\
\hline Marital status & Single=0, Married=1 \\
\hline $\begin{array}{c}\text { Education } \\
\text { level }\end{array}$ & Years of schooling: $0-23$ \\
\hline Eastern & Eastern=1 \\
\hline Central & Central $=2$ \\
\hline Western & Western $=3$ \\
\hline $\begin{array}{c}\text { Low education } \\
\text { level }\end{array}$ & Low level of education $=1$ \\
\hline $\begin{array}{c}\text { High } \\
\text { education level }\end{array}$ & High level of education $=2$ \\
\hline
\end{tabular}

\subsection{Model construction}

Firstly, this paper discusses the issue of residents' decision making, based on the question in the CFPS2018 questionnaire "Does your household currently hold financial products such as stocks, funds, treasury bonds, trust products, foreign exchange products, etc.?" A binary Probit model is developed to determine whether residents invest or not.

Of which: is the probability that residents will invest, is a cumulative standard normal distribution function, is the Z-index of the Probit model.

After determining residents' investment decisions through Probit model screening, the Tobit model is used to discuss the impact of the Digital Economy Inclusive Finance Index on the amount of investment generated due to the presence of truncated variables. Using resident investment as the explanatory variable and the Digital Inclusive Finance Index as the core explanatory variable, the direct impact of digital inclusive finance development on resident investment is verified. In addition to the effects generated by the Digital Inclusive Finance Index, there are also effects of residents' income, age and gender. Therefore, the Tobit model is constructed as follows.

Of which : lninvis the logarithm of resident investment, lnindis the logarithm of the digital financial inclusion index; denotes the set of control variables mentioned above that may affect residents' consumption, where total household income and net household assets are logged; is a random disturbance term. 


\section{EMPIRICAL RESULTS AND ANALYSIS}

\subsection{The impact of digital finance on residents' investment decisions}

In Table 2, this paper examines the impact of the total digital finance index and its three replacement indicators on residents' investment decisions, respectively. As shown in Table 3, the sample size of the model is 11,798 , and the digital finance index has a significant positive impact on investment decisions at the $1 \%$ level of the scale. The reasons for this may be as follows: first, the development of digital finance has helped to alleviate liquidity constraints and increased the reach of financial services, which also facilitates residents' investment decisions; second, the Internet development has increased access to financial services and brought more choices for residents to invest; third, the digital evolution of society has led to economic development in the provinces, thus indirectly prompting residents to invest.

In order to explore the robustness of the results, a robustness analysis was conducted using three secondary indicators of digital finance replacing the total indicator, and the results were found to have significant effects. Columns (2) to (4) of Table 3 show the effects of the breadth of digital finance coverage, depth of use and digitisation on residents' investment decisions, respectively. The results show that both the total digital finance index and the secondary segmentation indicators have a significant positive effect on residents' investment decisions. It can be concluded that the development of digital finance is broadly robust to the improvement of residents' investment decisions. Moreover, at the economic significance level, the secondary indicator of digitalisation has a larger estimated coefficient. Therefore, it has a stronger effect on improving residents' investment decisions thanhaving a stronger effect on improving residents' investment decisions than the breadth of coverage and depth of use. This suggests that digitalisation has the greatest impact on investment decisions due to digital financial inclusion improving the efficiency of credit services and the banking sector actively uses financial technology tools to improve the convenience of services. With the use of new technology, new channels and the management of financial chaos, the cost of micro and decentralized financing services in the banking sector has been effectively controlled, thus driving residential investment.
Table 2 The impact of digital finance on residents' investment decisions

\begin{tabular}{|c|c|c|}
\hline $\begin{array}{l}\text { Variable } \\
\text { name }\end{array}$ & Baseline regression & $\begin{array}{l}\text { Replacement } \\
\text { indicator }\end{array}$ \\
\hline $\begin{array}{l}\text { Digital } \\
\text { finance }\end{array}$ & $0.235 * * *(0.018)$ & \\
\hline $\begin{array}{l}\text { Breadth of } \\
\text { coverage }\end{array}$ & & $0.243 * * *(0.019)$ \\
\hline \multicolumn{3}{|l|}{ Depth of use } \\
\hline \multicolumn{3}{|l|}{$\begin{array}{c}\text { Degree of } \\
\text { digitisation }\end{array}$} \\
\hline Age & $0.001 * * *(0.000)$ & $0.001 * * *(0.000)$ \\
\hline Gender & $-0.007(0.004)$ & $-0.007(0.004)$ \\
\hline Health status & $-0.001(0.002)$ & $-0.001(0.002)$ \\
\hline Work status & $-0.010 *(0.005)$ & $-0.010 *(0.005)$ \\
\hline Marital status & $-0.005(0.007)$ & $-0.006(0.007)$ \\
\hline $\begin{array}{l}\text { Educational } \\
\text { attainment }\end{array}$ & $0.010 * * *(0.001)$ & $0.011 * * *(0.001)$ \\
\hline $\begin{array}{l}\text { Resident } \\
\text { income }\end{array}$ & $0.043 * * *(0.003)$ & $0.043^{* * *}(0.003)$ \\
\hline $\mathrm{N}$ & 11798 & 11798 \\
\hline $\begin{array}{l}\text { Variable } \\
\text { name }\end{array}$ & $\begin{array}{l}\text { Replacement } \\
\text { indicator }\end{array}$ & $\begin{array}{c}\text { Replacement } \\
\text { indicator }\end{array}$ \\
\hline \multicolumn{3}{|l|}{$\begin{array}{l}\text { Digital } \\
\text { finance }\end{array}$} \\
\hline \multicolumn{3}{|l|}{$\begin{array}{l}\text { Breadth of } \\
\text { coverage }\end{array}$} \\
\hline Depth of use & $0.158 * * *(0.013)$ & \\
\hline $\begin{array}{c}\text { Degree of } \\
\text { digitisation }\end{array}$ & & $0.433 * * *(0.334)$ \\
\hline Age & $0.001 * * *(0.000)$ & $0.001 * * *(0.000)$ \\
\hline Gender & $-0.007(0.004)$ & $-0.007(0.004)$ \\
\hline Health status & $-0.001(0.002)$ & $-0.001(0.002)$ \\
\hline Work status & $-0.010 *(0.005)$ & $-0.010 *(0.005)$ \\
\hline Marital status & $-0.006(0.007)$ & $-0.006(0.007)$ \\
\hline $\begin{array}{c}\text { Educational } \\
\text { attainment }\end{array}$ & $0.011 * * *(0.001)$ & $0.010 * * *(0.001)$ \\
\hline $\begin{array}{l}\text { Resident } \\
\text { income }\end{array}$ & $0.043 * * *(0.003)$ & $0.043 * * *(0.003)$ \\
\hline $\mathrm{N}$ & 11798 & 11798 \\
\hline
\end{tabular}

Note: ${ }^{*}, * *$ and $* * *$ indicate significant at the $10 \%, 5 \%$ and $1 \%$ levels respectively.

\subsection{The impact of digital finance on the amount of money residents invest}

In Table 3, this paper study the impact of the total digital finance index and its three replacements on the amount of investment made by residents, respectively.

After removing the truncated variables with the Tobit model, continuous variables that have made investments are studied, and the sample size of the model is 11,798 . It can be seen that the digital finance index has a significant impact on the amount of investment made by the residents at the $1 \%$ level. The reason for this may be that technology-enabled financial inclusion breaks down distance and geographical restrictions and enables more targeted services in the process of information sharing. Digital inclusive finance leads the way by building an 
inclusive financial product and service system that is efficient in operation, mutual assistance and sharing, and developed simultaneously online and offline, enabling accurate identification, fine management and precise services for target customers, and using technological innovation to alleviate the credit, information and motivation problems prominent in the inclusive finance sector, thus enabling residents to make financial investments with confidence.

Table 3 The impact of digital finance on the amount of money residents invest

\begin{tabular}{|c|c|c|}
\hline Variable name & Baseline regression & $\begin{array}{l}\text { Replacement } \\
\text { indicator }\end{array}$ \\
\hline Digital finance & $4.696 * * *(0.256)$ & \\
\hline $\begin{array}{l}\text { Breadth of } \\
\text { coverage }\end{array}$ & & $5.014 * * *(0.275)$ \\
\hline \multicolumn{3}{|l|}{ Depth of use } \\
\hline \multicolumn{3}{|l|}{$\begin{array}{c}\text { Degree of } \\
\text { digitisation }\end{array}$} \\
\hline Age & $0.012 * * *(0.002)$ & $0.013 * * *(0.002)$ \\
\hline Gender & $-0.124 * * *(0.048)$ & $-0.131 * * *(0.048)$ \\
\hline Health status & $-0.021(0.020)$ & $-0.021(0.020)$ \\
\hline Work status & $-0.104 *(0.058)$ & $-0.107 *(0.058)$ \\
\hline Marital status & $-0.127(0.083)$ & $-0.134(0.083)$ \\
\hline $\begin{array}{c}\text { Educational } \\
\text { attainment }\end{array}$ & $0.098 * * *(0.006)$ & $0.099 * * *(0.006)$ \\
\hline $\begin{array}{l}\text { Resident } \\
\text { income }\end{array}$ & $0.389 * * *(0.024)$ & $0.396^{* * *}(0.024)$ \\
\hline $\mathrm{N}$ & 11798 & 11798 \\
\hline Variable name & $\begin{array}{c}\text { Replacement } \\
\text { indicator }\end{array}$ & $\begin{array}{c}\text { Replacement } \\
\text { indicator }\end{array}$ \\
\hline \multicolumn{3}{|l|}{ Digital finance } \\
\hline \multicolumn{3}{|l|}{$\begin{array}{l}\text { Breadth of } \\
\text { coverage }\end{array}$} \\
\hline Depth of use & $2.731 * * *(0.164)$ & \\
\hline $\begin{array}{c}\text { Degree of } \\
\text { digitisation }\end{array}$ & & $8.353^{* * *}(0.456)$ \\
\hline Age & $0.012 * *(0.002)$ & $0.011 * *(0.002)$ \\
\hline Gender & $-0.117 * *(0.048)$ & $-0.123 * *(0.048)$ \\
\hline Health status & $-0.023(0.020)$ & $-0.023(0.020)$ \\
\hline Work status & $-0.110 *(0.058)$ & $-0.105 *(0.058)$ \\
\hline Marital status & $-0.145 *(0.083)$ & $-0.143 *(0.083)$ \\
\hline $\begin{array}{c}\text { Educational } \\
\text { attainment }\end{array}$ & $0.099 * * *(0.006)$ & $0.099 * * *(0.006)$ \\
\hline Resident income & $0.401 * * *(0.024)$ & $0.390 * * *(0.024)$ \\
\hline $\mathrm{N}$ & 11798 & 11798 \\
\hline
\end{tabular}

\subsection{Heterogeneity analysis}

Finally, heterogeneity analysis was conducted, Some scholars have already studied the unevenness of China's digital economy development in terms of regional differences so this paper firstly also carries out a regional heterogeneity analysis: secondly, as different levels of education affect the residents' analytical skills and financial knowledge base, as well as their investment and the amount of investment. Therefore, a heterogeneity analysis of education levels is required.

As China is a vast country with different levels of economic development in different regions, which may result in variability in the impact of digital finance on residents' investment, this part is firstly divided into three parts to analyze variability in the east, west and central regions. The result is the analysis of regional heterogeneity in Table 5, with a valid sample size of 5187 in the east, 3382 in the central region and 3229 in the west. experimental results It can be seen that the total digital finance index is significant at $1 \%$ level in the eastern region and central region, while it is not significant in the western region. It indicates that the impact of digital finance on the amount of investment by residents is significant in the eastern and central regions, while the impact of digital finance on the amount of investment by residents is insignificant in the western region. The reason for this may be that although digital financial inclusion can break through geographical constraints, in theory, it is still constrained by geography in practice. As a new financial business model, the development of digital finance still depends on a certain traditional financial base and level of economic development. The eastern coastal region has a strong financial base, and cities with a high level of digital inclusive finance development are clustered in this region. In contrast, the financial base in the central and western regions is relatively weak, and most cities have a low level of digital inclusive finance development.

Table 4 The impact of digital finance on residential investment - an estimate of regional heterogeneity

\begin{tabular}{|c|c|c|c|}
\hline Variable name & Eastern & Central & Western \\
\hline Digital finance & $5.930 * * *(0.454)$ & $3.345^{* * *}(1.002)$ & $0.222(0.647)$ \\
\hline Age & $0.017 * * *(0.004)$ & $0.014 * * *(0.003)$ & $0.009^{* * *}(0.003)$ \\
\hline Gender & $-0.052(0.087)$ & $-0.317 * * *(0.079)$ & $-0.182 * * *(0.063)$ \\
\hline Health status & $-0.027(0.037)$ & $-0.022(0.032)$ & $0.020(0.025)$ \\
\hline Work status & $-0.086(0.105)$ & $-0.087(0.091)$ & $-0.136^{*}(0.081)$ \\
\hline Marital status & $-0.091(0.147)$ & $-0.146(0.148)$ & $-0.111(0.104)$ \\
\hline $\begin{array}{c}\text { Educational } \\
\text { attainment }\end{array}$ & $0.140 * * *(0.011)$ & $0.107 * * *(0.010)$ & $0.061 * * *(0.007)$ \\
\hline $\begin{array}{c}\text { Resident } \\
\text { income }\end{array}$ & $0.512 * * *(0.045)$ & $0.290^{* * *}(0.041)$ & $0.193^{* * *}(0.031)$ \\
\hline $\mathrm{N}$ & 5187 & 3382 & 3229 \\
\hline
\end{tabular}

Note: $* * *$ and $* * *$ indicate significant at the $10 \%, 5 \%$ and $1 \%$ levels respectively.

Due to the different education levels of residence, the groups were grouped according to the median and divided into two groups of low and high education levels for the analysis of heterogeneity. The results are shown in the heterogeneity analysis of education levels in Table 5, with a valid sample size of 8495 for low education levels and 3303 for high education levels. it is clear from the results of the experiment that the level of significance of the total digital finance index is the same in the low education level group and the high education level group, 
both at the $1 \%$ level of significance. It means that the impact of digital finance on the amount of investment of residents is significant in both groups. However, when comparing the coefficients, the impact of digital finance on investment is greater in the high education level group. The reason may be that digital finance relies on innovative technologies such as information technology, big data and cloud computing, which further expand the scope of services and reach of inclusive finance, but making financial investments requires residents to have the certain financial knowledge and the ability to choose financial products, while the high-education level group has more knowledge base and stronger judgment ability compared to the low-education level group.

Table 5 The impact of digital finance on residential investment - an estimate of heterogeneity in educational attainment

\begin{tabular}{|c|c|c|c|}
\hline Variable name & $\begin{array}{c}\text { Low education } \\
\text { level }\end{array}$ & $\begin{array}{c}\text { High education } \\
\text { level }\end{array}$ & $\mathrm{p}$ \\
\hline Digital finance & $3.263 * * *(0.212)$ & $7.110 * * *(0.669)$ & 0.000 \\
\hline Age & $0.005 * * *(0.002)$ & $0.028 * * *(0.006)$ & 0.000 \\
\hline Gender & $-0.031(0.038)$ & $-0.085(0.137)$ & 0.285 \\
\hline Health status & $-0.011(0.015)$ & $0.008(0.065)$ & 0.330 \\
\hline Work status & $-0.147 * *(0.045)$ & $-0.146(0.179)$ & 0.500 \\
\hline Marital status & $-0.083(0.078)$ & $-0.037(0.187)$ & 0.380 \\
\hline $\begin{array}{c}\text { Educational } \\
\text { attainment }\end{array}$ & $0.024 * * *(0.006)$ & $0.290 * * *(0.037)$ & 0.000 \\
\hline $\begin{array}{c}\text { Resident } \\
\text { income }\end{array}$ & $0.217 * * *(0.018)$ & $0.958 * * *(0.082)$ & 0.000 \\
\hline $\mathrm{N}$ & 8495 & \multicolumn{2}{|c|}{3303} \\
\hline
\end{tabular}

Note: $*, * *$ and $* * *$ indicate significant at the $10 \%, 5 \%$ and $1 \%$ levels respectively. $\mathrm{p}$ is the test for difference in coffiecients between two groups

\section{CONCLUSION}

By constructing the probit model and the Tobit model, this paper finds that digital finance has a positive impact on investment decisions and investment amounts. To this end, it uses big data, cloud computing, through the advantages of digital finance sharing, convenience, security, low cost and low threshold artificial intelligence technologies to build a data-based risk control system, thus enhancing the risk control capability of finance and promoting residents' investment across the board. Through the analysis of regional heterogeneity, it is learned that the development of digital finance should not be generalised, and different policies should be implemented for different regions according to local conditions. For the backward regions in the west, it is more important to strengthen the construction of financial services, expand financial service channels, classify financial products, popularise financial investment knowledge and promote financial investment among residents. For the eastern and central regions, we should standardise financial services and reduce the cost of financial investment in a reasonable and effective way. In addition, the role of financial inclusion for higher education groups to make investments is more significant, indicating that the cultivation of financial capabilities of low-education groups should be strengthened, financial investment knowledge should be popularised through multiple channels, and the financial services market should provide different financial products for different groups.

This paper enriches the existing research by providing an in-depth study of the relationship between digital finance and investment, and also provides a differentiated analysis by region and education level, respectively. For the healthy development of the financial investment market, future breakthroughs can be made in the following areas: (1) Extending the radius of financial services, expanding the coverage of financial services and improving the imbalance in the allocation of financial resources. (2) Financial service institutions should introduce diverse financial products and improve the quality of financial services. (3) Continue to optimise the commercial sustainability of inclusive finance and enhance the enthusiasm of financial institutions to participate in inclusive finance.

\section{REFERENCES}

[1]Xiao Zuping, Zhang Xinzhe. Study on the Impact of System and Human Capital on The Participation of Household Financial Markets - Survey Data from Private Entrepreneurs in China, Economic Research, 2012, 47 (S1): 91-104.

[2]Yin Zhichao, Song Quanyun, Wu Yu. Financial Knowledge, Investment Experience and Family Asset Selection, Economic Research, 2014, 49 (04): 62-75.

[3]Meng Yijia. Cognitive Competence and Family Asset Selection Economic Research, 2014, 49 (S1): 132142.

[4]Lei Xiaoyan, ZhouYuegang. Chinese Household Portfolio Selection: Health Status and Risk Appetite Financial Research, 2010 (01): 31-45.

[5] Li Tao, Liu YuCan. Decision-making mechanisms of heterogeneous individuals in collective action - an empirical study based on a residential community survey[A]. School of Economics, Zhejiang University, Institute of Economic Research (Center), Shandong University, Editorial Department of Economic Research. 2006 (4th) Conference Proceedings of China Law and Economics Forum [C]. School of Economics, Zhejiang University, Institute of Economic Research (Center), Shandong University, Editorial Department of Economic Research:Institute of Economic Research, Shandong University, 2006:8. 
[6]Meng JuanJuan ,Zhao LongKai, Liu YuZhen ,You Wei. Social learning, herd mentality and stock market participation decisions $[\mathrm{J}]$. Financial Research,2013(07):153-165.

[7] WangJin , Wu Weixing. The impact of marriage on household risky asset choice[J]. Nankai Economic Research,2014(03):100-112.

[8]Lin Bo. Macroeconomic policies and household financial asset choice[D]. University of International Business and Economics,2018.

[9]Zhou Guangsu ,Liang Qi. Internet use, market frictions and household investment in risky financial assets[J]. Financial Research,2018(01):84-101.

[10]Guo Feng, Wang JingYi, Wang Fang, Kong Tao, Zhang Xun, Cheng ZhiYun, "Measuring the development of digital inclusive finance in China: Index compilation and spatial characteristics", Quarterly Journal of Economics, Vol. 19, No. 4, 2020. 